\title{
METABOLIC ADJUSTMENTS DURING SEMI-AESTIVATION OF THE MARBLE SWAMP EEL (Synbranchus marmoratus, Bloch 1795) - A FACULTATIVE AIR BREATHING FISH
}

\author{
MORAES, G., ALTRAN, A. E., AVILEZ, I. M., BARBOSA, C. C. and BIDINOTTO, P. M. \\ Laboratório de Bioquímica Adaptativa, Departamento de Genética e Evolução, \\ Rod. Washington Luís, km 235, CEP 13565-905, Sao Carlos, SP, Brazil \\ Correspondence to: Gilberto Moraes, Laboratório de Bioquímica Adaptativa, Departamento de Genética e Evolução, \\ Rod. Washington Luís, km 235, CEP 13565-905, Sao Carlos, SP, Brazil, e-mail: gil@ power.ufscar.br \\ Received July 28, 2003 - Accepted October 30, 2003 - Distributed May 31, 2005
}

\begin{abstract}
Metabolic changes, principally in intermediary metabolism and nitrogen excretion, were investigated in the marble swamp eel (Synbranchus marmoratus) after 15 and 45 days of artificially induced semi-aestivation. Glucose, glycogen, lactate, pyruvate, free amino acids, triglycerides, ammonia, urea, and urate contents were determined in liver, kidney, white muscle, heart, brain, and plasma. Lactate dehydrogenase, glutamate dehydrogenase, malate dehydrogenase, aspartate amino transferase, alanine amino transferase, glutamine synthase, ornithine carbamoyl transferase, and arginase enzymes were assayed. The teleost $S$. marmoratus maintained initial energetic demands by lipid oxidation. The course of normal oxidative processes was observed through tissue enzyme profiles. After the lipid stores were exhausted, the fish consumed body proteins. Constant values of hematocrit during induced semi-aestivation suggested that the water balance remained normal. Therefore, the surrounding water was probably did not trigger the semi-aestivation in this teleost. Decrease of ammonia and increase of renal urea synthesis after 45 days of semi-aestivation led to the assumption that an alternative form of eliminating ammonia exists. Metabolic changes entailed by starvation were proposed to explain the biosynthesis of small molecules involved in the semi-aestivation of S. marmoratus.
\end{abstract}

Key words: semi-aestivation, metabolism, adaptation, Synbranchus marmoratus, nitrogen excretion.

\section{RESUMO}

Ajustes metabólicos do muçum (Synbranchus marmoratus, Bloch 1795) um peixe de respiração aérea facultativa - durante semi-estivação

Foram investigadas variações metabólicas em muçum (Synbranchus marmoratus) após 15 e 45 dias de semi-estivação artificial induzida, com ênfase no metabolismo intermediário e excreção de nitrogênio. Glicose, glicogênio, lactato, piruvato, aminoácidos livres, triglicerídios, amônia, uréia e uratos foram determinados em fígado, rim, músculo branco, coração, cérebro, e plasma. As enzimas lactato desidrogenase, glutamato desidrogenase, malato desidrogenase, aspartato amino transferase, alanina amino transferase, glutamina sintetase, ornitina carbamil transferase e arginase foram ensaiadas. O teleósteo S. marmoratus manteve sua demanda energética inicial pela oxidação de lipídios. A sequiência normal dos processos oxidativos foi observada por meio do perfil enzimático. Após o consumo das reservas lipídicas, os peixes passaram a consumir proteína. Valores constantes de hematócrito durante a semi-estivação induzida sugeriu que o balanço de água foi mantido normal. Todavia, a água ambiental provavelmente não foi o sinal inicial da semi-estivação em $S$. marmoratus. A diminuição de amônia e o aumento da síntese de uréia renal após 45 dias de semi-estivação levaram a assumir que existe uma forma alternativa de eliminar amônia. As variações metabólicas conseqüentes do jejum prolongado foram propostas como responsáveis pela síntese de pequenas moléculas envolvidas na semi-estivação de $S$. marmoratus.

Palavras-chave: semi-estivação, metabolismo, adaptação, Synbranchus marmoratus, excreção de nitrogênio. 


\section{INTRODUCTION}

Freshwater Neotropical organisms are often exposed to drastic environmental fluctuations. Among these, the most significant are oxygen concentrations (Graham et al., 1978; Dunn et al., 1983), tides (Brooks \& Storey, 1997), temperature (Brooks \& Storey, 1997), and even water availability in several temporary lagoons and ponds (Val, 1995). External changes trigger immediate organismal responses to cope with stressors (Romer, 1966; Thomson, 1980; Bray, 1985; Long, 1995). Among the various organic strategies, metabolic arrest is a mechanism observed in many amphibians, reptiles, and mollusks (Abe, 1995; Brooks \& Storey, 1997). This response, usually called aestivation, seems to be initiated by absence of oxygen (Brooks \& Storey, 1997; Hochachka et al., 1997); however, this is not common in fish. Nevertheless, during dry periods, a number of species exposed to air have been reported to aestivate in mud (Rosen \& Greenwood, 1976; Bicudo \& Johansen, 1979). Although these fish are air-breathing species, impairment of oxygen uptake may occur, which would justify aestivation. However, lack of surrounding water has also been proposed as a probable signal for observed metabolic arrest (Hochachka \& Guppy, 1987). Reduced oxygen availability leads to several metabolic changes, e.g., lactate increase and glycogen mobilization (Hochachka \& Somero, 1984), and even a need for protein catabolism (Dave et al., 1975; Mommsen et al., 1980; Smith, 1981; Wood \& Fung, 1981; Moon, 1983). Moreover, the absence of surrounding water requires nitrogen metabolism adjustments.

The impossibility of eliminating ammonia under such circumstances results in hyperammonemia, which requires alternative ways to avoid toxicity (Walsh et al., 1990; Barber \& Walsh, 1993; Walsh et al., 1994). Synthesis of glutamine has been reported in airbreathing fish (Iwata \& Kakuta, 1983) and glutamine accumulation has been observed in the brain of various teleosts exposed to high levels of ammonia (Korsgaard et al., 1995). The facultative air-breathing fish Oxyeleotris marmoratus activates hepatic glutamine synthase during exposure to air (Jow et al., 1999). However, ammonia can be also be wasted through urea synthesis. A set of ornithine-urea cycle enzymes has been reported for some teleost species. Moreover, specific environmental conditions such as those created by ammonia increase (Saha \& Ratha, 1994; Saha et al., 1999; Moraes \& Polez, 2004b), alkaline waters
(Randall et al., 1989; Moraes \& Polez, 2004a), and confinement and/or crowding (Walsh et al., 1990; Walsh \& Milligan, 1995) augment the presence of these enzymes. The Neotropical facultative airbreather Synbranchus marmoratus (marble swamp eel) is able to survive up to three months embedded in mud (Bicudo \& Johansen, 1979), carrying out the gas-exchange process in the buccopharyngeal epithelium and in the branchial chamber. Under these inhospitable conditions, the animal, in a typically torpid state, sometimes stretches the body, sliding on its own mucus within the mud tunnels. This behavior, called semi-aestivation, requires adjustments in the overall metabolism, thereby raising the following questions: Is this species highly tolerant to ammonia or does the presence of ammonia increase trigger a strategy to overcome toxicosis? Does the absence of surrounding water, by impairing oxygen exchange, result in cellular fermentation? Is the reduced availability of water a signal likely to cause semi-aestivation? The aim of this study was to correlate the metabolic responses of the marble swamp eel with the induced semi-aestivation process.

\section{MATERIAL AND METHODS}

Adult S. marmoratus weighing $300 \mathrm{~g} \pm 50$ were collected in late spring from the Tietê River, Ibitinga, São Paulo, Brazil, (48 49'W 21 $\left.{ }^{\circ} 45^{\prime} \mathrm{S}\right)$ and taken to the laboratory. Their new environment consisted of 250 $\mathrm{L}$ tanks with clean, filtered water at $25^{\circ} \mathrm{C}$, constant aeration, and natural photoperiod. The fish were acclimatized for 30 days and fed on live bait. After acclimation, 24 fish were transferred to a wide fiberglass box containing $15 \mathrm{~cm}$ of mud covered with $15 \mathrm{~cm}$ of water. The water was then slowly drained, leaving the box completely empty after 48 hours. When the fish detected the drainage they burrowed into the mud. Two periods of semi-aestivation (15 and 45 days) were assayed. Another group of 24 fish were taken from the clean water tanks, transferred to identical conditions described above, but kept without drainage (control). After $24 \mathrm{~h}$, eight fish were sampled (time-control zero). The sixteen remaining fish were sampled at the end of the first span (day 15) and at the end of the trials (day 45). The fish were randomly collected after day 15 and day 45, transferred to glass aquaria, and anesthetized with $0.27 \mathrm{~g} / \mathrm{L}$ of MS222, following which blood samples were taken. The animals were then killed, and liver, brain, kidney, heart, and white muscle excised and immediately frozen into liquid nitrogen. 


\section{Plasma extract}

Whole blood aliquots were used in hematocrit and $\mathrm{pH}$ determinations. Blood samples were centrifuged at $12,000 \times \mathrm{G}$ for $3 \mathrm{~min}$. To each proper aliquot of supernatants was added $20 \%$ trichloroacetic acid (TCA), followed by centrifugation at $12,000 \times \mathrm{G}$ for $3 \mathrm{~min}$. The supernatants were used as acid extracts.

\section{Tissue extracts}

Liver, brain, kidney, heart, and white muscle were mechanically homogenized $1: 10$ with $20 \%$ TCA using 30 s strokes of a 2,000 rpm motor-driven Teflon pestle. The acid homogenates were centrifuged at $12,000 \times \mathrm{G}$ for $3 \mathrm{~min}$, and glucose and lactate were determined in the supernatants. Amino acids were quantified in homogenized liver, kidney, and white muscle, as described above, in 5 volumes of cold distilled water. The homogenates were centrifuged at $12,000 \times \mathrm{G}$ for $3 \mathrm{~min}$ and 1 volume of $0.3 \mathrm{~N} \mathrm{Ba}$ $(\mathrm{OH})_{2}$ and $5 \% \mathrm{ZnSO}_{4}$ was added to the supernatant. The cloudy, white precipitate was centrifuged at $12,000 \times \mathrm{G}$ for $3 \mathrm{~min}$ and the pellets discarded.

\section{Metabolites}

Metabolic intermediates were colorimetrically determined. Reducing sugars were estimated with phenol-sulphuric acid (Dubois et al., 1956); lactate, with p-hydroxiphenyl phenol (Harrower \& Brown, 1972); pyruvate, by dinitrophenyl hydrazine- $\mathrm{NaOH}$ (Lu, 1939); free amino acids, by ninhidrine (Copley, 1941); ammonia, by nesslerization (Gentzkow \& Masen, 1942); urea, by diacetyl monoxime (Rahmatullah \& Boyde, 1980); and urate, by carbonate-phosphotungstate (Henry et al., 1957). Triglycerides were determined by the enzymaticcolorimetric test (McGowan et al., 1983).

Tissue samples from the liver, kidney, and white muscle were completely dissolved in 10 volumes of $6 \mathrm{~N} \mathrm{KOH}$ in a boiling-water bath for $3 \mathrm{~min}$ to determine glycogen (Bidinotto et al., 1997). The extract was transferred 1:10 v/v to ethanol; 1 volume of $10 \%$ $\mathrm{K}_{2} \mathrm{SO}_{4}$ was added to improve precipitation. The pellet was re-suspended in $3.0 \mathrm{ml}$ of distilled water and glucose was determined in a proper aliquot using phenol-sulfuric acid (Dubois et al., 1956).

\section{Enzyme assay}

Liver, kidney, brain, heart, and white muscle were mechanically homogenized with four $15 \mathrm{sec}$ strokes in a cold-water bath with a motor-driven Teflon pestle at 2,000 rpm. Homogenization was carried out in $0.1 \mathrm{M}$ sodium phosphate buffer, $\mathrm{pH} 7.0$, centrifuged at $5,000 \times \mathrm{G}$ for $5 \mathrm{~min}$, and the supernatant was used as an enzyme source to determine alanine amino transferase (ALAT) (EC 2.6.1.2) and aspartate amino transferase (AAT) (EC 2.6.1.1) (Reitman \& Frankel, 1957); lactate dehydrogenase (LDH) (EC 1.1.1.27), malate dehydrogenase (MDH) (EC 1.1.1.37), and glutamate dehydrogenase (GDH) (EC 1.4.1.2) (Hochachka et al., 1978); glutamine synthase (GS) (EC 6.3.1.2) (Vorhaben et al., 1973), ornithine carbamoyl transferase (OCT) (EC 2.1.3.3) (Nakamura \& Jones, 1970), and arginase (ARG) (EC 3.5.3.1) (Rahmatullah \& Boyde, 1980). All enzymes were assayed at $25^{\circ} \mathrm{C}$.

\section{Statistics}

The data are presented as averages \pm SD. The significance of differences between averages $(\mathrm{p}<$ $0.05)$ was tested using two-way variance analysis (ANOVA). Whenever differences between averages were found, Tukey-Kramer multiple comparison tests were applied.

\section{Results}

Significant metabolic adjustments were observed in the semi-aestivated marble swamp eel. Hematocrit (45\%) and blood $\mathrm{pH}(7.7)$ remained unaltered during both aestivation spans. The liver, kidney, and white muscle glycogen bulk decreased $56 \%, 46 \%$, and $36 \%$, respectively. Glucose dropped in liver, remained constant in kidney and heart, and rose in brain and white muscle. Pyruvate concentration increased in kidney and white muscle. Lactate concentration was slightly reduced in the liver and markedly so in other tissues. A sharp increase of amino acids was observed in liver, kidney, and white muscle.

These data are presented in Table 1. Plasma pyruvate and amino acids increased after 45 days of semi-aestivation. Plasma triglyceride concentration decreased to undetectable values, while glucose declined significantly. Plasmatic ammonia fluctuated throughout the semi-aestivation period, increasing after 15 days and slowing down at the end. Plasma urea increased and urate did so only after 15 days of semi-aestivation, reaching close to basal levels after 45 days. These results are located in Table 2 .

Changes were observed in the activity of the intermediary metabolism enzymes AAT, ALAT, GDH, $\mathrm{LDH}$, and $\mathrm{MDH}$, as shown in Table 3. The aminotransferases AAT and ALAT increased in liver and white muscle, particularly after 15 days of semiaestivation. Glutamate dehydrogenase increased slightly in white muscle, but showed a significant increase in the liver, heart, and brain. Lactate 
dehydrogenase remained constant in the liver but increased in the heart and brain, while malate dehydrogenase increased only in the heart and brain. The enzymes GS, OCT, and ARG involved in nitrogen excretion were assayed in liver and kidney tissue.
Except for arginase, the liver and kidney showed different responses (Table 4). Glutamine synthase and ornithine carbamoyl transferase decreased in the liver and increased in the kidney. Arginase increased significantly in both liver and kidney.

TABLE 1

Metabolic profile of $S$. marmoratus under induced semi-aestivation.

\begin{tabular}{|c|c|c|c|c|c|c|}
\hline \multirow{2}{*}{ Tissue } & \multirow{2}{*}{$\Delta \mathbf{t}$} & \multicolumn{5}{|c|}{ Metabolite } \\
\hline & & Glycogen & Glucose & Pyruvate & Lactate & FAA \\
\hline \multirow{3}{*}{ Liver } & $C$ & $308 \pm 63$ & $275 \pm 31$ & $0.63 \pm 0.03$ & $20.42 \pm 10.1$ & $1.5 \pm 0.1$ \\
\hline & $A_{15}$ & $365 \pm 35$ & $280 \pm 21$ & $0.83 \pm 0.03$ & $22.23 \pm 6.8$ & $1.6 \pm 0.1$ \\
\hline & $A_{45}$ & $135 \pm 20 *$ & $190 \pm 16^{*}$ & $0.97 \pm 0.09$ & $15.74 \pm 5.6$ & $19.7 \pm 0.1 *$ \\
\hline \multirow{3}{*}{ Kidney } & $C$ & $62 \pm 3$ & $25 \pm 1$ & $0.27 \pm 0.02$ & $18.77 \pm 3.5$ & $2.1 \pm 0.2$ \\
\hline & $A_{15}$ & $32 \pm 5^{*}$ & $21 \pm 3$ & $0.47 \pm 0.03$ & $11.08 \pm 3.8^{*}$ & $1.4 \pm 0.1$ \\
\hline & $A_{45}$ & $33 \pm 4 *$ & $24 \pm 4$ & $1.18 \pm 0.16^{*}$ & $8.12 \pm 1.5^{*}$ & $16.3 \pm 3.5^{*}$ \\
\hline \multirow{3}{*}{$\begin{array}{l}\text { White } \\
\text { muscle }\end{array}$} & $C$ & $11 \pm 1$ & $20 \pm 2$ & $0.55 \pm 0.05$ & $22.41 \pm 2.3$ & $4.3 \pm 0.9$ \\
\hline & $A_{15}$ & $9 \pm 1$ & $23 \pm 4$ & $0.76 \pm 0.08^{*}$ & $25.15 \pm 1.3^{*}$ & $2.0 \pm 0.2 *$ \\
\hline & $A_{45}$ & $7 \pm 1 *$ & $28 \pm 2 *$ & $0.46 \pm 0.04$ & $20.81 \pm 2.3$ & $15.3 \pm 1.7 *$ \\
\hline \multirow{3}{*}{ Heart } & $C$ & $n-m$ & $88 \pm 9$ & $n-m$ & $28.44 \pm 8.5$ & $n-m$ \\
\hline & $A_{15}$ & $\mathrm{n}-\mathrm{m}$ & $67 \pm 7$ & $\mathrm{n}-\mathrm{m}$ & $22.85 \pm 2.5$ & $\mathrm{n}-\mathrm{m}$ \\
\hline & $A_{45}$ & $n-m$ & $95 \pm 9$ & $n-m$ & $18.01 \pm 2.7^{*}$ & $n-m$ \\
\hline \multirow{3}{*}{ Brain } & $C$ & $\mathrm{n}-\mathrm{m}$ & $19 \pm 3$ & $\mathrm{n}-\mathrm{m}$ & $30.43 \pm 5.6$ & $\mathrm{n}-\mathrm{m}$ \\
\hline & $A_{15}$ & $n-m$ & $19 \pm 2$ & $\mathrm{n}-\mathrm{m}$ & $28.55 \pm 2.65$ & $n-m$ \\
\hline & $A_{45}$ & $n-m$ & $25 \pm 2 *$ & $n-m$ & $15.16 \pm 2.69 *$ & $n-m$ \\
\hline
\end{tabular}

Glycogen is expressed as $\mu \mathrm{mol}$ of glucosyl-glucose/g of wet tissue; the other metabolites are expressed as $\mu \mathrm{mol} / \mathrm{mg}$ of wet tissue. $\mathrm{FAA}=$ free amino acids, $\mathrm{C}=$ control, $\mathrm{A}_{1}=$ aestivation for 15 days, $\mathrm{A} 2=$ aestivation for 45 days, $(*)$ significantly different compared to the control $(\mathrm{p}<0.05) . \mathrm{n}-\mathrm{m}=$ not measured.

TABLE 2

Plasma metabolite of $S$. marmoratus under induced aestivation.

\begin{tabular}{|c|c|c|c|}
\hline \multirow{2}{*}{ Metabolite } & \multicolumn{3}{|c|}{ Condition } \\
\cline { 2 - 4 } & $7.90 \pm 0.85$ & $\boldsymbol{A}_{15}$ & $\boldsymbol{A}_{45}$ \\
\hline Glucose & $0.19 \pm 0.03$ & $5.38 \pm 0.83^{*}$ & $0.07 \pm 0.63^{*}$ \\
\hline Pyruvate & $2.16 \pm 0.09$ & $0.23 \pm 0.02$ & $2.01 \pm 0.54$ \\
\hline Lactate & $4.25 \pm 0.99$ & $2.43 \pm 0.26$ & $9.55 \pm 0.80^{*}$ \\
\hline FAA & $52.71 \pm 5.42$ & $3.94 \pm 0.36$ & $\mathrm{n}-\mathrm{d}$ \\
\hline TG & $3.02 \pm 0.05$ & $11.85 \pm 0.68^{*}$ & $0.80 \pm 0.09^{*}$ \\
\hline Ammonia & $0.89 \pm 0.19$ & $3.98 \pm 0.32^{*}$ & $1.93 \pm 0.11^{*}$ \\
\hline Urea & $0.21 \pm 0.09$ & $1.27 \pm 0.18$ & $0.22 \pm 0.02$ \\
\hline Urate & $0.49 \pm 0.05^{*}$ & 0.29 \\
\hline
\end{tabular}

Triglycerides are expressed in $\mathrm{mg} / \mathrm{dL}$ of plasma; the other metabolites are expressed as $\mu \mathrm{mol} / \mathrm{mg}$ of wet tissue. FAA $=$ free amino acids, $\mathrm{TG}=$ triglycerides, $\mathrm{C}=$ control, $\mathrm{A} 1=$ aestivation for 15 days, $\mathrm{A} 2=$ aestivation for 45 days, $\mathrm{n}-\mathrm{d}=$ not detected, $(*)$ significantly different compared to the control $(\mathrm{p}<0.05)$. 
TABLE 3

Enzyme response of $S$. marmoratus to induced aestivation.

\begin{tabular}{|c|c|c|c|c|c|c|c|}
\hline \multirow{2}{*}{ Tissue } & \multirow{2}{*}{$\mathbf{t}$} & \multicolumn{6}{|c|}{ Enzyme } \\
\hline & & AAT & ALAT & \multicolumn{2}{|c|}{ GDH } & LDH & MDH \\
\hline \multirow{3}{*}{ Liver } & $C$ & $2.64 \quad 0.21$ & $3.85 \quad 0.35$ & 12.44 & 1.39 & $3.4 \quad 0.3$ & $18.8 \quad 2.1$ \\
\hline & $A_{15}$ & $8.980 .93^{*}$ & $9.80 \quad 0.91 *$ & 13.84 & 1.31 & $3.3 \quad 0.3$ & $18.4 \quad 2.1$ \\
\hline & $A_{45}$ & $13.30 \quad 0.96 *$ & $4.05 \quad 0.20$ & 22.30 & $2.90 *$ & $\begin{array}{ll}3.2 & 0.3 \\
\end{array}$ & $\begin{array}{ll}17.9 & 1.2 \\
\end{array}$ \\
\hline \multirow{3}{*}{ White muscle } & $C$ & $1.74 \quad 0.28$ & $1.47 \quad 0.18$ & 9.12 & 1.32 & $414.1 \quad 24$ & $1.4 \quad 0.1$ \\
\hline & $A_{15}$ & $3.02 \quad 0.30 *$ & $2.58 \quad 0.27 *$ & 6.93 & 0.82 & $240.328 *$ & $\begin{array}{ll}1.3 & 0.1 \\
\end{array}$ \\
\hline & $A_{45}$ & $0.72 \quad 0.01$ & $1.71 \quad 0.13$ & 11.53 & 1.15 & $394.1 \quad 6$ & $1.4 \quad 0.1$ \\
\hline \multirow{3}{*}{ Heart } & $C$ & $n-a$ & $\mathrm{n}-\mathrm{a}$ & 5.09 & 0.86 & $115.4 \quad 10$ & $23.4 \quad 1$ \\
\hline & $A_{15}$ & $\mathrm{n}-\mathrm{a}$ & $\mathrm{n}-\mathrm{a}$ & 9.89 & $1.23^{*}$ & $232.1 \quad 14^{*}$ & $47.3 \quad 3^{*}$ \\
\hline & $A_{45}$ & $\mathrm{n}-\mathrm{a}$ & $\mathrm{n}-\mathrm{a}$ & 8.50 & $0.68 *$ & $267.218 *$ & $43.4 \quad 2 *$ \\
\hline \multirow{3}{*}{ Brain } & $C$ & $n-a$ & $\mathrm{n}-\mathrm{a}$ & 4.18 & 0.63 & 81.28 & 6.10 .6 \\
\hline & $A_{15}$ & $\mathrm{n}-\mathrm{a}$ & $\mathrm{n}-\mathrm{a}$ & 5.89 & $0.35 *$ & $118.311 *$ & $9.90 .9 *$ \\
\hline & $A_{45}$ & $\mathrm{n}-\mathrm{a}$ & $\mathrm{n}-\mathrm{a}$ & 5.92 & $0.68 *$ & $104.4 \quad 11$ & $8.30 .5^{*}$ \\
\hline
\end{tabular}

AAT $=$ aspartate amino transferase, ALAT $=$ alanine amino transferase, $\mathrm{GDH}=$ glutamic dehydrogenase, $\mathrm{LDH}=$ lactic dehydrogenase, $\mathrm{MDH}=$ malic dehydrogenase, $\mathrm{C}=$ control, $\mathrm{A} 1=$ aestivation for 15 days, $\mathrm{A} 2=$ aestivation for 45 days, $(\mathrm{n}-$ a) not assayed, $(*)$ significantly different compared to the control $(\mathrm{p}<0.05)$.

TABLE 4

Nitrogen metabolism enzymes of $S$. marmoratus under induced semi-aestivation.

\begin{tabular}{|c|c|c|c|c|}
\hline \multirow{3}{*}{$\begin{array}{l}\text { Tissue } \\
\text { Liver }\end{array}$} & \multirow{3}{*}{$\begin{array}{r}\mathbf{t} \\
C\end{array}$} & \multicolumn{3}{|c|}{ Enzyme } \\
\hline & & GS & OCT & ARG \\
\hline & & $0.10 \quad 0.01$ & $0.42 \quad 0.02$ & $13.1 \quad 1.0$ \\
\hline & $A_{15}$ & $n-d$ & $0.32 \quad 0.02 *$ & $17.1 \quad 1.9$ \\
\hline & $A_{45}$ & $n-d$ & $0.03 \quad 0.00^{*}$ & $21.5 \quad 2.1^{*}$ \\
\hline \multirow[t]{3}{*}{ Kidney } & $C$ & $0.05 \quad 0.00$ & $0.07 \quad 0.01$ & $10.9 \quad 0.9$ \\
\hline & $A_{15}$ & $0.10 \quad 0.01 *$ & $0.350 .03^{*}$ & $5.2 \quad 0.5 *$ \\
\hline & $A_{45}$ & $0.12 \quad 0.01 *$ & $0.36 \quad 0.04 *$ & $17.91 .6 *$ \\
\hline
\end{tabular}

GS = glutamine synthase, $\mathrm{OCT}=$ ornithine carbamoyl transferase, $\mathrm{ARG}=$ arginase, $\mathrm{C}=$ control, $\mathrm{A} 1=$ aestivation for 15 days, $\mathrm{A} 2=$ aestivation for 45 days, $(\mathrm{n}-\mathrm{d})$ not detected, $(*)$ significantly different compared to the control $(\mathrm{p}<0.05)$.

\section{DISCUSSION}

A number of aquatic organisms, particularly freshwater ones, are occasionally exposed to harsh environmental conditions. Droughts, for instance, may reduce lakes and lagoons to small ponds containing predominantly mud and very little water, consequently threatening the lives of many species, particularly fish. For them to survive to continue in such conditions requires special adaptive mechanisms for coping with many stressors, such as temperature, decrease of oxygen, water turbidity, and even predators. Some teleost species adopt similar behaviors to withstand such circumstances. The lungfish Protopterus and Lepidosiren, for example, dig into the mud to aestivate (Hochachka \& Somero, 1971). In drought conditions, the bi-modal breathing fish $S$. marmoratus lies in little tunnels and covers itself with mucus, so remaining until the rainy season begins (Bicudo \& Johansen, 1979). 
Metabolic demands of the fish must be supplied by organismal storages during the dormant state.

An outcome of induced semi-aestivation in the marble swamp eel was the increase of free amino acids in all assayed tissues, which suggested bodyprotein consumption. Supplying metabolic demands in this way has previously been reported in eels (Dave et al., 1975; Moon, 1983). However, lipid breakdown would be more advantageous from many points of view. Such a metabolic option has just been reported in the sea bass Dicentrarchus labrax when starved; however, a very stressing condition does not necessarily imply aestivation (Echeverría et al., 1997). The exhaustion of fat stores in the marble swamp eel was inferred from the complete depletion of plasma triglycerides after 45 days of semi-aestivation. Lipid catabolism is a metabolic choice providing high energy yield, but requiring fully functioning oxidative pathways.

The oxidative process during semi-aestivation can be assumed from the tissue enzyme profile. Both glycolytic and oxidative metabolisms have been previously reported in the very specialized cardiac muscle of $S$. marmoratus (French \& Hochachka, 1978). Indeed, the observed increase of heart dehydrogenases activity is probably the way this species makes up for reduced primary metabolite production. Lactate produced by other tissues has been proposed as an energy source for heart muscle (Collins \& Anderson, 1997; Hochachka \& Hulbert, 1978). The fermentative picture observed in white muscle of the marble swamp eel bears out this proposition. The increase of LDH and white muscle lactate suggests a fermentative preference at the beginning of the process. However, at the end of a long-term semi-aestivation the metabolic responses of both white and cardiac muscles converged to a similar pattern of physiological adjustment.

The oxidative profile of the hepatic tissue remained unchanged throughout the semiaestivation period. However, increased activity of nitrogenous metabolism was evidenced by transaminases plus the free amino-acids outline. The lessening of hepatic glycogen and glucose suggest the role of the liver as a glucose supplier through glycogenolysis and gluconeogenesis.

The nervous system of marble swamp eel may have been the main consumer of glucose released by liver. Brain catabolism remained constant throughout the semi-aestivation span. The observed increase of dehydrogenases activity was likely triggered to maintain cell viability; lactate was probably used as energy supplier. Therefore, the general metabolic preference of the brain in $S$. marmoratus under semi-aestivation was basically aerobic, and the oxygen approach was independent of surrounding water.

Considering that hematocrit was kept constant during the trials, the water balance is supposed not to have been impaired; hence, it is difficult to assume any role of the external water supply as a signal to begin semi-aestivation. The observed increase of plasma amino acids should be the result of high protein catabolism. The rise in plasma ammonia concentration might have been expected, however, it decreased about fourfold while the urea doubled. These values are very close to an equimolar rate and, therefore, very suggestive of urea synthesis as a strategy for eliminating ammonia in the absence of environmental water. The kidney seems pivotal in such a process, and the arginase increase was likely the primary consequence of amino acid catabolism. This hypothesis is rendered more likely by the OCT and CS increases of about five and twofold, respectively. The liver seems to work differently and its role, if any, in nitrogen excretion is probably of little relevance.

The metabolic profile of the marble swamp eel under semi-aestivation would be typical of fasting if acidemia had been observed; however, blood $\mathrm{pH}$ remained constant. Direct correlation between aestivation and fasting, as reported by Janssens (1964) and DeLaney et al. (1977), seems not probable in the case of $S$. marmoratus. Nevertheless, starvation-related metabolites may possibly act as signals for aestivation. For instance, the rise of urea-synthesis enzymes means increase of ornithine and arginine, intermediates believed to increase polyamine concentrations. Such molecules play a role in the regulation of many protein syntheses (Aoyama, 1989, 1990). Moreover, the hyperuricemia observed in the first 15 days of aestivation can result from overactive metabolism of informational molecules during the initial phases of metabolic adjustments. New evidence must be found regarding the role of small molecules in general metabolism, such as those mentioned above, in which different metabolic processes are triggered and/or adjusted in response to environmental factors.

In conclusion, catabolism of amino acids and lipids plays an important role in the process of 
supplying energy for the semi-aestivated $S$. marmoratus. Fat stores of the animals used were depleted in 45 days and aerobic metabolism was not suppressed. The reduction of lactate in every tested tissue, the small amount of urea synthesized after 45 days of semi-aestivation, and the animals' general torpor were suggestive of very slow metabolism. The water balance was not disturbed and ammonia excretion was shifted toward urea synthesis and its waste. Regarding intermediary metabolism, a role is being proposed for small molecules in assisting the physiological adjustments of $S$. marmoratus in the semi-aestivation process.

Acknowledgements — The authors thank technicians Antonio Aparecido da Silva and Luis Henrique da Silva, and their colleagues in the Laboratório de Bioquímica Adaptativa for logistical support. This study was sponsored by the Conselho Nacional de Pesquisas $(\mathrm{CNPq})$.

\section{REFERENCES}

ABE, A. S., 1995, Estivation in the South American amphibians and reptiles. Braz. J. Med. Biol. Res., 28: 11-12.

AOYAMA, H., 1990, Spermine stimulates the threonyl-tRNA formation in rat liver. Chem.-Biol. Interac., 74(1-2): 33-43.

AOYAMA, H., 1989, Spermine stimulates RNA-dependent reverse transcriptase activity. Biochem. Intern., 19(1): 67-76.

BARBER, M. L. \& WALSH, P. J., 1993, Interactions of the acidbasic status and nitrogen excretion and metabolism in the ureogenic teleost, Opsanus beta. Journal of Experimental Biology, 185: 87-105.

BICUDO, J. E. P. W. \& JOHANSEN, K., 1979, Respiratory gas exchange in the air - breathing fish, Synbranchus marmoratus. Environ.l Biol. Fishes, 4: 55-64.

BIDINOTTO, P. M., SOUZA, R. H. S. \& MORAES, G., 1997, Hepatic glycogen in eight tropical fresh water teleost fish: A procedure for field determinations of micro samples. Bol. Téc. CEPTA, Pirassununga, 10: 53-60.

BRAY, A. A., 1985, The evolution of the terrestrial vertebrates: Environmental and physiological considerations. Philos. Trans. Royal Soc. London Series B-Biological Sciences, London, 309: 289-322.

BROOKS, S. P. J. \& STOREY, K. B., 1997, Glycolitic controls in aestivation and anoxia: a comparison of metabolic arrest in land and marine molluscs. Comp. Biochem. Physiol. A., 118(4): 1103-1114.

COLLINS, A. L. \& ANDERSON, T. A., 1997, The influences of changes in food availability on the activities of key degradative and metabolic enzymes in the liver and epaxial muscle of the golden perch. J. Fish. Biol., 50: 1158-1165. doi:10.1006/jfbi.1997.0386.

COPLEY, N. G., 1941, Alloxan and ninhydrin test. The Analyst., 66: 492-493.
DAVE, G., JOHANSSON-SJØBECK, M. L., LARSSON, A., LEWANDER, K. \& LIDMAN, U., 1975, Metabolic and hematological effects of starvation in the European eel, Anguilla anguilla L. - I. Carbohydrate, lipid, protein and inorganic ion in metabolism. Comp. Biochem. Physiol. A., 52: 423-430.

DeLANEY, R. G., LAHIRI, S., HAMILTON, R. \& FISHMAN, A. P., 1977, Acid-base balance and plasma composition in the aestivating lungfish (Protopterus). Am. J. Physiol., 232(1): R10-R17.

DUBOIS, M., GILLES, K. A., HAMILTON, J. K., REBERS, P. A. \& SMITH, F., 1956, Colorimetric method for determination of sugars and related substances. Anal. Chem., 28(3): 350356 .

DUNN, J. F., HOCHACHKA, P. W., DAVISON, W. \& GUPPY, M., 1983, Metabolic adjustments to diving and recovery in the African lungfish. Am. J. Physiol., 245: R651-R657.

ECHEVARRÍA, G., MARTÍNEZ-BEBIÁ, M. \& ZAMORA, S., 1997, Evolution of biometric indices and plasma metabolites during prolonged starvation in European sea bass (Dicentrarchus labrax, L.). Comp. Biochem. Physiol., A 118(1): 111-123.

FRENCH, C. J. \& HOCHACHKA, P. W., 1978, Lactate dehydrogenase isozymes from heart and white muscle of waterbreathing and air-breathing fish from the Amazon. Can. J. Zool., 56: 769-773.

GENTZKOW, C. J. \& MASEN, J. M., 1942, An accurate method for the determination of blood urea nitrogen by direct nesslerization. J. Biol. Chem., 143: 531-544.

GRAHAM, J. B., KRAMER, D. L. \& PINEDA, E., 1978, Comparative respiration of an air breathing and a non air breathing characoid fish and the evolution of aerial respiration in characins. Physiol. Zool., 51: 279-288.

HARROWER, J. R. \& BROWN, C. H., 1972, Blood lactic acid. A micro method adapted to field collection of microliters samples. J. Appl. Physiol., 32(5): 244-228.

HENRY, R. J., SOBEL, C. \& KIM, J., 1957, A modified carbonatephosphotungstate method for the determination of uric acid and comparison with the spectrophotometric uricase method. Am. J. Clin. Path., 28(2): 152-160.

HOCHACHKA, P. W. \& HULBERT, W. C., 1978, Glycogen 'seas', glycogen bodies, and glycogen granules in heart and skeletal muscle of two air-breathing, borrowing fishes. Can. J. Zool., 56(4), 774-786.

HOCHACHKA, P. W. \& SOMERO, G. N., 1971, Biochemical adaptation to the environment. In: W. S. Hoar \& D. J. Randall (eds.), Fish Physiology. Academic Press., New York and London, Vol. VI, pp. 100-148.

HOCHACHKA, P. W. \& SOMERO, G. N., 1984, Biochemical Adaptation. Princeton University Press, 537p.

HOCHACHKA, P. W. \& GUPPY, M., 1987, Metabolic arrest and the control of biological time. Cambridge, Harvard University Press.

HOCHACHKA, P. W., LAND, S. C. \& BUCK, L. T., 1997, Oxygen sensing and signal transduction in metabolic defense against hypoxia: lessons from vertebrate facultative anaerobes. Comp. Biochem. Physiol., A 118(1): 23-29. 
HOCHACHKA, P. W., GUPPY, M., GUDERLEY, H. E., STOREY, K. B. \& HULBERT, W. C., 1978, Metabolic biochemistry of water vs air breathing fishes: muscle enzymes and ultrastructure. Can. J. Zool., 56(4): 736-750.

IWATA, K. \& KAKUTA, I., 1983, A comparison of catalytic properties of glutamate dehydrogenase from liver and muscle between amphibious Periophthalmus cantonensis and waterbreathing gobid fishes Tridentiger obscurus obscurus. Bul. Japanese Soc. Scien. Fisheries, 49: 1903.

JANSSENS, P. A., 1964, The metabolism of the aestivating African lungfish. Comp. Biochem. Physiol., 11: 105-117.

JOW, L. Y., CHEW, S. F., LIM, C. B., ANDERSON, P. M. \& IP, Y. K., 1999, The marble goby Oxyeleotris marmoratus activates hepatic glutamine synthetase and detoxifies ammonia to glutamine during air exposure. Journal of Experimental Biology, 202(3): 237-245.

KORSGAARD, B., MOMMSEN, T. P. \& WRIGHT, P. A., 1995, Nitrogen excretion in teleostean fish: Adaptive relationships to environment, ontogenesis and viviparity. In: P. J. Walsh \& P. Wright (eds.), Nitrogen Metabolism and Excretion. CRC Press.

LONG, J. A., 1995, The rise of fishes: 500 million years of evolution. Johns Hopkins University Press, Baltimore, 233p.

LU, G. D., 1939, The metabolism of pyruvic acid in normal and vitamin B-deficient state. I. A rapid specific and sensitive method for the estimation of blood pyruvate. Bioch. J., 33: 249-254.

MCGOWAN, M. W., ARTISS, J. D., STRANDBERGH, D. R. \& ZORK, B., 1983, A peroxidase-coupled method for the colorimetric determination of serum triglycerides. Clin. Chem., $29,538-542$.

MOMMSEN, T. P., FRENCH, C. J. \& HOCHACHKA, P. W., 1980, Sites and pattern of protein and amino acid utilization during the spawning migration of salmon. Can. J. Zool., 58: 1785-1799.

MOON, T. W., 1983, Metabolic reserves and enzyme activities with food deprivation in immature American eel, Angilla rostrata. Can. J. Zool., 67: 2189-2193.

MORAES, G. \& POLEZ, V. L. P., 2004a, Ureotelism is inducible in Neotropical freshwater Hoplias malabaricus (Teleostei, Erythrinidae). Braz. J. Biol., (64): 2.

MORAES, G. \& POLEZ, V. L. P., 2004b, Biochemical responses of two Erythrinidae fish to environmental ammonia. Braz. J. Biol., 64(1).

NAKAMURA, M. \& JONES, M. E., 1970, Ornithine Carbamyltransferase (Streptococcus faecalis). In: S. P. Colowick \& N. O. Kaplan (eds.), Methods in Enzymology. Academic Press, New York, Vol. XVII, Part A, Section IV, chapter 32, pp. 289-294.

RAHMATULLAH, M. \& BOYDE, T. C., 1980, Improvements in the determination of urea using diacetyl monoxime: methods with and without deproteinization. Clinica Chimica Acta, 107: 3-9.
RANDALL, D. J., WOOD, C. M., PERRY, S. F., BERGMAN, H., MALOIY, G. M. O., MOMMSEN, T. P. \& WRIGHT, P. A., 1989, Urea excretion as a strategy for survival in fish living in very alkaline environment. Nature, 337: 165-166.

REITMAN, S. \& FRANKEL, S. A., 1957, A colorimetric method for determination of serum glutamic oxaloacetic and glutamic pyruvic transaminases. Amer. J. Clin. Path., 28: 56.

ROMER, A. S., 1966, Vertebrate Paleontology. University of Chicago Press, Chicago, 468p.

ROSEN, D. E. \& GREENWOOD, P. H., 1976, A fourth neotropical species of synbranchid eel and the phylogeny and systematics of sinbranchiform fishes. Bul. Amer. Museum Nat. Hist., 157: $1-69$.

SAHA, N. \& RATHA, B. K., 1994, Induction of ornithine-urea cycle in a freshwater teleost, Heteropneustes fossilis, exposed to high concentrations of ammonium chloride. Comp. Biochem. Physiol., 108B: 315-325.

SAHA, N., DAS, L. \& DUTTA, S., 1999, Types of carbamyl phosphate synthetases and subcellular localization of urea cycle and related enzymes in air-breathing walking catfish, Clarias batrachus. J. Exp. Zool., 283(2): 121-130.

SMITH, M. A. K., 1981, Estimation of growth potential by measurement of tissue protein synthetic rates in feeding and starvation rainbow trout Salmo gairdneri R. J. Fish Biol., 19: 213-22.

THOMSON, K. S., 1980, The ecology of the lobe-finned fish. In: A. L. Panchen (ed.), The terrestrial environment and the origin of land vertebrates. Academic Press, London, pp. 187222.

VAL, A. L., 1995, Oxygen transfer in fish: Morphological and Molecular Adjustments. Braz. J. Med. Biol. Res., 28: 11191127.

VORHABEN, J. E., WONG, L. \& CAMPBELL, J. W., 1973, Assay for glutamine synthetase activity. J. Biochem., 135: 893-896.

WALSH, P. J. \& MILLIGAN, C. L., 1995, Effects of feeding and confinement on nitrogen-metabolism and excretion in the gulf toadfish Opsanus beta. Journal of Experimental Biology, 198(7): 1559-1566.

WALSH, P. J., DANULAT, E. \& MOMMSEN, T. P., 1990, Variation in urea excretion in the gulf toadfish, Opsanus beta. Marine Biol., 106: 323-328.

WALSH, P. J., TUCKER, B. C. \& HOPKINS, T. E., 1994, Effects of confinement/crowding on ureogenesis in the gulf toadfish, Opsanus beta. Journal of Experimental Biology, 191: 195206.

WOOD, N. Y. S. \& FUNG, A. C. Y., 1981, Studies on the biology of the red sea bream. IV. Metabolic effects of starvation at low temperature. Comp. Biochem. and Physiol., 69A: 461-468. 